\title{
Microscopical Aspects Concerning the Presence snd Distribution of Mitochondria in Intralobular and Interlobular Ducts from Rat Parotid Gland
}

\author{
Vasile RUS ${ }^{1}$, Bianca MATOSZ ${ }^{1}$, Flavia RUXANDA ${ }^{1 *}$, Sidonia BOGDAN ${ }^{1}$, Cristian RAȚIU ${ }^{2}$, Viorel MICLĂUȘ ${ }^{1}$ \\ ${ }^{1}$ Faculty of Veterinary Medicine, USAMV Cluj-Napoca, Romania \\ ${ }^{2}$ Faculty of Medicine and Pharmacy, University of Oradea, Romania \\ *corresponding author: flavia.ruxanda@gmail.com
}

Bulletin UASVM Veterinary Medicine 73(2) / 2016,

Print ISSN 1843-5270; Electronic ISSN 1843-5378

DOI:10.15835/buasvmcn-vm: 12185

\begin{abstract}
Saliva secreted by acini from parotid gland is concentrated in the excretory ducts. This study aims to highlight certain microscopical aspects concerning the presence, density and disposition of mitochondria in intralobular and interlobular ducts from parotid parenchyma in rats. In the intralobular ducts' segment lined by cuboidal cells, mitochondria are present throughout the whole cytoplasm, without a regular arrangement. In the area where cells are columnar, mitochondria become more numerous and most of them are disposed in the basal half and have a regular disposition (perpendicular to the basal pole). In the interlobular ducts, mitochondria are somehow less, but their disposition is similar to the one in the previous segment. In intralobular ducts with a thin wall, mitochondria have an irregular disposition and are present throughout the whole cytoplasm, while in striated and interlobular ducts, they have a regular disposition, perpendicularly on the basal pole of the cell and most of them are concentrated in the basal half of the cell.
\end{abstract}

Keywords: ducts, mitochondria, parotid, rat

\section{INTRODUCTION}

Parotid gland is formed out of sustaining tissue and parenchyma. Parenchyma is represented by glandular acini and excretory ducts (Miclăuş, 2012). In human and rodent parotid gland, it contains serous acini (Amano et al., 2012). Saliva secreted by acini ends up in the intralobular ducts, which in turn continue with the interlobular ones. The latter type of ducts merge and form Stenon's duct. The first segment is represented by intercalated ducts, which continue with the striated ones (Gal and Miclăuș, 2013). Saliva secreted by acini is concentrated in striated ducts (Aughey and Frye, 2001) by changing the electrolyte composition (Evans et al., 1993), reasorbtion of sodium, probably mediated by $\mathrm{Na}^{+}-\mathrm{K}^{+}$ATP-ase (Tandler et al., 2001). Organization of the basal cytoplasm of the ductal cells reflects their involvement in water and electrolytes transport (Raica et al., 2004), thus the main function of striated ducts is to transform saliva from isotonic to hypotonic (Tandler et al., 2001). In the subnuclear region of striated ducts, there are numerous striations, perpendicular on the basement membrane, due to the presence of mithocondria, with a parallel arrangement among them and to the long axis of the cell (Diculescu et al., 1971; Lantini et al., 1990). This study aims to highlight certain microscopical aspects concerning the presence, density and disposition of mitochondria in intralobular and interlobular ducts from parotid parenchyma in rats. 


\section{MATERIAL AND METHODS}

We harvested $3 \mathrm{~mm}$ thick samples from the parotid of five male Wistar rats, weighing about $180 \mathrm{~g}$. The fragments were fixed in Orth's solution for 24 hours long. After fixation, the samples were washed with distilled water and subsequently postchromized in $3 \%$ potassium dichromate solution for 7 days long, changing the solution daily. The samples were washed 24 hours under tap water, dehydrated with ethanol, clarified with butanol and embedded in $56^{\circ} \mathrm{C}$ paraffin. We sectioned $4 \mu \mathrm{m}$ slices from the paraffin blocks. For tissue contrasting, we stained the slides with Heidenhain's iron hematoxylin.

\section{RESULTS AND DISCUSSIONS}

In the intralobular ducts' segment lined by cuboidal cells, mitochondria have a medium density and dispose throughout the whole cytoplasm without significant density differences among the basal and apical pole of the cell. Upon their appearance on the section surface, mitochondria have an an irregular arrangement, being oriented in all directions throughout the cytoplasm (Fig. 1).

In the part where the intalobular ducts' wall becomes columnar (striated ducts), mitochondria appear to be more numerous in comparison to the anterior segment. Most of the mitochondria are disposed in the basal half of the cell and have an arranged disposition, parallel one to another and perpendicularly on the basement membrane. In the apical half of the cells, mitochondria are fewer, with a less arranged disposition. Moreover, mitochondria present in the apical half seem to be somehow shorter than the ones present in the basal half (Fig. 2).

In the interlobular ducts, mitochondria's density is somehow lower in comparison to the previous segment, without any differences regarding their disposition (Fig. 3).

The presence of mitochondria in relatively large numbers in intralobular ducts sustains the fact that cells utilize a large quantity of energy, aspect also signaled by other authors (Evans et al., 1993; Aughey and Frye, 2001; Tandler et al., 2001).

Regarding the disposition of mitochondria in striated ducts, the obtained results are similar to the ones described by other authors (Diculescu et al., 1971; Lantini et al., 1990), except that they do not signal the presence of mitochondria in the apicalhalf of the cells. The presence of mitochondria in interlobular ducts in relatively large numbers, with the same disposition as in striated ducts, suggests the fact that the electrolyte reabsorbtion process continues up to this segment.

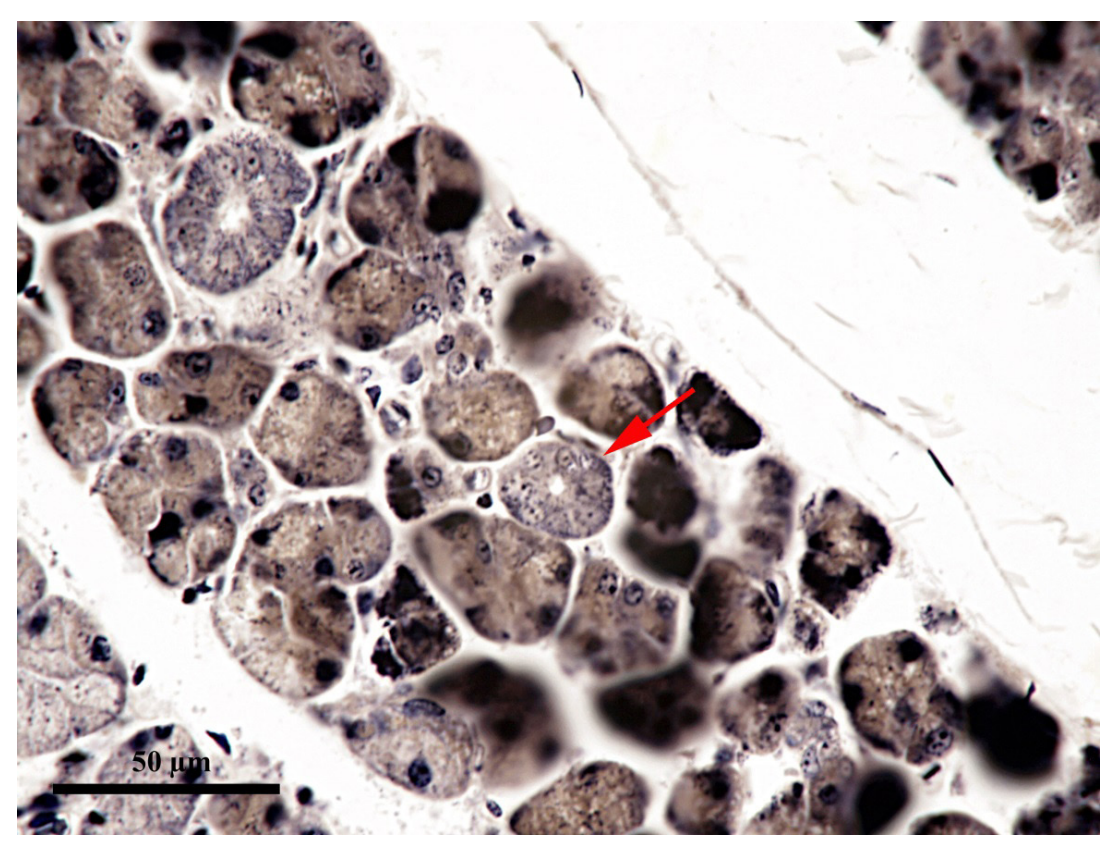

Fig. 1. Intralobular duct lined by cuboidal cells Heidenhain's iron hematoxylin, red arrow - basal pole 


\section{CONCLUSIONS}

In intralobular ducts lined by cuboidal cells, mitochondria dispose in all directions and are present in both basal and apical half, without density differences. In intralobular ducts, whose walls are formed out of columnar cells, most of the mitochondria are disposed in the basal half and are parallel among them and perpendicularly on the basal membrane, while the apical part contains less mitochondria, oriented in all directions. In interlobular ducts, mitochondria have a similar disposition to the one in the striated ducts, but they are less numerous.

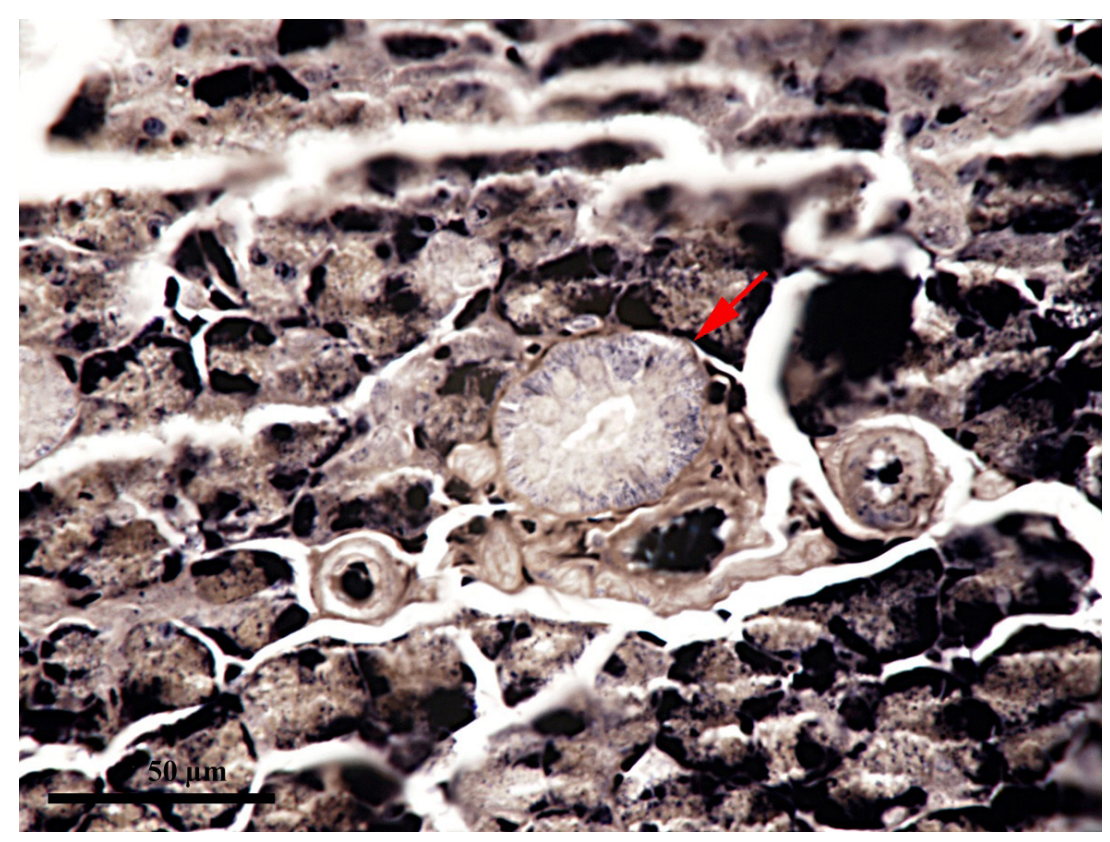

Fig. 2. Intralobular duct lined by columnar cells Heidenhain's iron hematoxylin, red arrow - basal pole

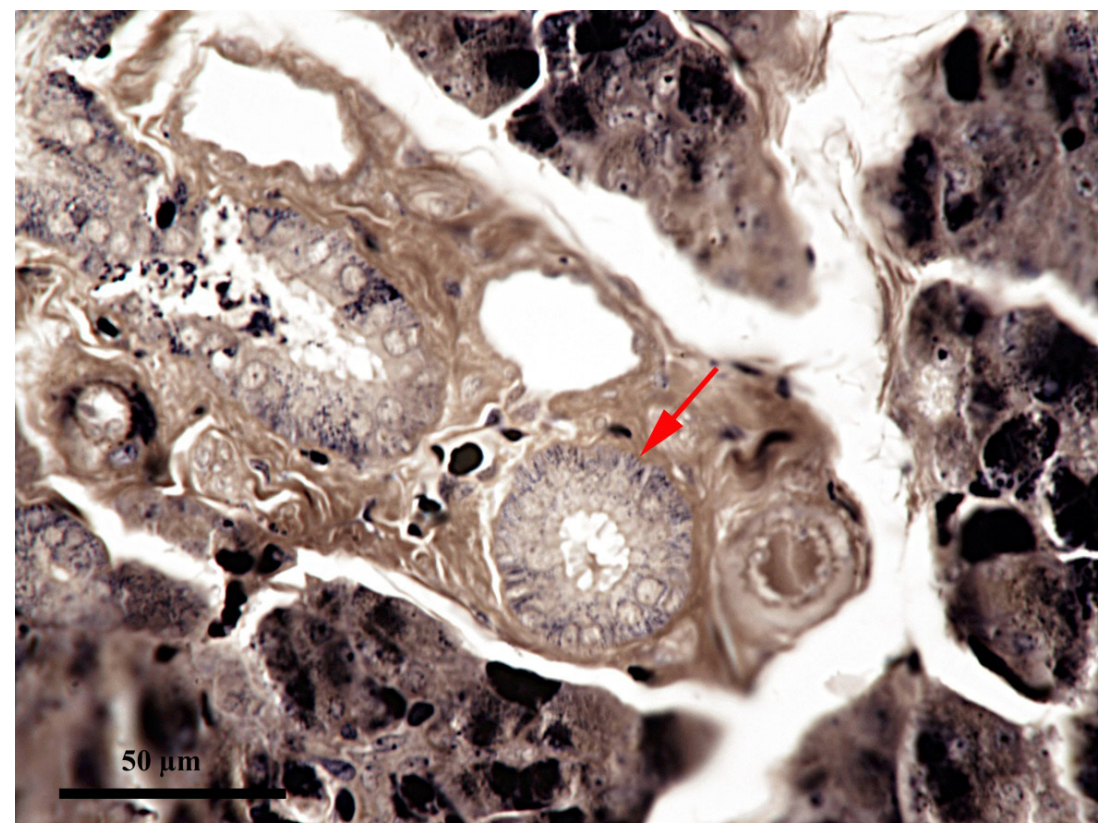

Fig. 3. Interlobular duct Heidenhain's iron hematoxylin, red arrow - basal pole 


\section{REFERENCES}

1. Amano O, Mizobe K, Bando Y, Sakiyama K (2012). Anatomy and Histology of Rodent and Human Major Salivary Glands. Acta Histochem Cytochem 45(5), 241-250.

2. Aughey E, Frey FL (2001). Comparative veterinary histology whith clinical correlates, Manson Publishing, London.

3. Diculescu I, Onicescu, Rimniceanu C (1971). Histologie, Partea a III-a, Editura didactică și pedagogică, București.

4. Evans RL, Lau KR, Case RM (2013). Structural and functional characterization of striated ducts isolated from the rabbit mandibular salivary gland. Exp Physiol 78(1):49-64.

5. Gal AF, Miclăuș v (2013). Histology. Editura Risoprint, Cluj-Napoca.
6. Lantini MS, Proto E, Puxeddu P, Riva A, Testa Riva F (1990). Fine structure of excretory ducts of human salivary glands, J Submicrosc Cytol Pathol 22(3):465-75.

7. Miclăuș V (2012). Histologie specială și embriologie generală, ediția a II-a, Editura Risoprint, Cluj-Napoca.

8. Raica M, Mederle O, Căruntu ID, Pintea A, Chindriș AM (2004). Histologie teoretică și practică, Editura Brumar, Timișoara.

9. Tandler B, Gresik EW, Nagato T, Phillips CJ (2001). Secretion by Striated Ducts of Mammalian Major Salivary Glands: Review From an Ultrastructural, Functional, and Evolutionary Perspective. The Anatomical Record 264:121-145. 